\title{
Reaction of melon accessions to crater rot and resistance inheritance
}

\author{
Ítala JB Nascimento ${ }^{1}$; Glauber HS Nunes ${ }^{1}$; Rui Sales Júnior ${ }^{1}$; Katchen JP Silva ${ }^{1}$; Izabel M Guimarães ${ }^{1}$; \\ Sami J Michereff ${ }^{2}$ \\ ${ }^{1}$ UFERSA, C. Postal 137, 59625-900 Mossoró-RN; glauber@ufersa.edu.br; ${ }^{2}$ UFRPE-Depto. Agronomia, Av. Dom Manoel de Medeiros \\ s/n, 52171-900 Recife-PE; sami@depa.ufrpe.br
}

\begin{abstract}
The aims of the present study were to assess the reaction of melon accessions to crater rot, caused by Myrothecium roridum, and study the inheritance of resistance. In the first experiment, 30 melon accessions from northeastern Brazil were assessed in a randomized block design with two replicates. Each plot was formed by a row of 12 plants, from which three fruits were sampled and used for inoculation. Each fruit was inoculated at four equidistant sites on the surface. Ten wounds were made at each site to an approximate depth of $3.0 \mathrm{~mm}$, to which $0.05 \mathrm{~mL}$ of conidial suspension was placed at a concentration of $10^{6}$ spores $\mathrm{mL}^{-1}$ of sterilized distilled water with the aid of a pipette. The fruits were placed on Petri dishes and enveloped in polyethylene bags containing hydrophilic cotton, both of which were moistened with sterilized distilled water. Five days after inoculation, the injured area (in $\mathrm{mm}^{2}$ ) was assessed. Accessions A-9, A-14 and A-30 were resistant to the CMM-609 isolate of M. roridum. In the second experiment, the parents AF-682 and UFERSA-05 were used as standards of susceptibility and resistance, respectively. From these plants, generations $\mathrm{F}_{1}, \mathrm{~F}_{2}, \mathrm{RC}_{11}$ and $\mathrm{RC}_{12}$ were obtained. The six populations were grown under field conditions in a randomized block design. Resistance to crater rot on the melon fruits exhibited complex inheritance, with six loci and the involvement of additive and dominance effects.
\end{abstract}

Keywords: Cucumis melo, Myrothecium roridum, germplasm, genetic control, poligenes.

\section{RESUMO}

Reação de acessos de meloeiro à podridão-de-cratera e herança da resistência

Os objetivos do presente trabalho foram avaliar a reação de germoplasma de meloeiro à podridão-de-cratera, causada por Myrothecium roridum, e estudar a herança da resistência. No primeiro experimento, foram avaliados 30 acessos de meloeiro coletados no Nordeste brasileiro. O delineamento experimental utilizado foi em blocos ao acaso com duas repetições. Cada parcela foi formada por uma linha com 12 plantas, da qual três frutos foram amostrados e utilizados para inoculação. Cada fruto foi inoculado em quatro regiões equidistantes na superfície. Em cada região foram realizados 10 ferimentos de aproximadamente $3,0 \mathrm{~mm}$ de profundidade. Nestes foram depositados $0,05 \mathrm{~mL}$ da suspensão de conídios na concentração de $10^{6}$ esporos $\mathrm{mL}^{-1}$ de água destilada esterilizada por meio de uma pipeta. Os frutos foram colocados sobre placas de Petri e envoltos em sacos de polietileno, contendo algodão hidrófilo, ambos umedecidos com água destilada esterilizada. A avaliação foi efetuada cinco dias após a inoculação determinando-se a área lesionada $\left(\mathrm{em} \mathrm{mm}^{2}\right)$. Os acessos A-9, A-14 e A-30 foram resistentes ao isolado CMM-609 de Myroyhecium roridum. No segundo experimento, foram utilizados os genitores AF-682 e UFERSA-05, como padrões de suscetibilidade e resistência, respectivamente. A partir dos mesmos foram obtidas as gerações $\mathrm{F}_{1}, \mathrm{~F}_{2}, \mathrm{RC}_{11}$ e $\mathrm{RC}_{12}$. As seis populações foram cultivadas em condições de campo em blocos ao acaso. A resistência à podridão-de-cratera em frutos do meloeiro teve herança complexa, com seis loci e envolvimento de efeitos aditivo e de dominância.

Palavras-chave: Cucumis melo, Myrothecium roridum, germoplasma, controle genético, poligenes.

\section{(Recebido para publicação em 23 de fevereiro de 2011; aceito em 20 de junho de 2012)} (Received on February 23, 2011; accepted on June 20, 2012)

$\mathrm{T}_{\mathrm{s}=\mathrm{s}}^{\mathrm{s}}$ he semiarid region of Brazil has climatic conditions that are favorable to the cultivation of different tropical vegetables and fruits, among which the melon (Cucumis melo) is one of the most important. The expansion of melon crops in northeastern Brazil accounted for $98.36 \%$ of the national melon production in 2010, with the states of Ceará (60.88\%) and Rio Grande do Norte (37.48\%) figuring prominently (MDICE, 2011). Besides the yield and considerable contribution to the national economy, melon agribusiness plays an important social role by employing a large contingent of laborers.

Despite efforts on the part of melon growers to improve the quality and quantity of the fruit, a number of plant health problems have hampered these initiatives. Crater rot caused by Myrothecium roridum is one of the more serious problems. The disease was first detected in Brazil in 1991 in the municipality of Mossoró (Rio Grande do Norte state) (Silva et al., 1996) and has since occurred with frequency in crops in the region (Senhor, 2006).

Myrothecium roridum is a soilborne fungus and has a broad host range. The pathogenesis of crater rot is associated with the production of enzymes and toxins. In melons, this fungus causes symptoms on the stems, leaves, roots and fruits. Crater rot on melons is characterized by surface and deeper lesions often in the form of a crater measuring 2 to $50 \mathrm{~mm}$ in diameter, in which olive-green fructifications (sporodochia) and dark exudates are produced. The fungus can become a parasite when environmental conditions are favorable to its development (Bruton, 1996). The occurrence of fungal rots on melons in the field is 
generally associated with warm, humid environmental conditions and the presence of injured fruits (Viana et al., 2001).

The dissemination of spores from infected to healthy parts of plants occurs mainly through the rainfall drops or irrigation. When the temperature is favorable and wounds are found on the tissue of the host plant, rain drops contribute significantly to the disease progress (Bruton, 1996). Assessing different inoculation methods, Senhor et al. (2006) found larger lesions on fruits inoculated using the method of wounds placed at equidistant sites, with no symptoms found on fruits without wounds. On melon plants, injuries may occur due to friction between the melons and the soil surface, cuts by instruments or rocks and the activity of insects, such as scraping of the surface, bites or penetration for feeding purposes (Viana et al., 2001). Moreover, melon producers periodically turn the fruits over to avoid the phenomenon denominated "white belly" caused by excess moisture on the lower portion of the fruit, which lowers its value; this conduct can also cause injury to the melons.

Studying the effects of inoculation methods, number of wounds on the fruit and age of the fruit on crater rot in the varieties AF-682 and Orange Flesh, Senhor et al. (2006) found that inoculation by sub-epidermal injection led to smaller lesions and that disease severity increased with the increase in the number of wounds, reaching a maximum with 10 wounds. The authors also found a tendency toward a reduction in disease severity with the increase in the age of the wounds, as lesions were significantly smaller on fruits injured six hours prior to inoculation in comparison to those inoculated immediately following injury. Moreover, the age of the fruit was not a determinant of either an increase or reduction in the severity of crater rot.

The different strategies currently employed for the control of $M$. roridum have demonstrated a poor degree of efficacy, which is why the use of resistant varieties is the measure of choice for the integrated management of crater rot. However, there are few reports on the reaction of melon genotypes inoculated with $M$. roridum in different plant parts. The literature reports the results of studies carried out to investigate the reaction in leaves (Kuti et al., 1987), which are rare symptoms in crops in northeastern Brazil, and in the neck of the plant (Silva et al., 1993; Lima et al., 1997; Noronha et al., 2006). Senhor et al. (2008) report the susceptibility of a simple hybrid of the yellow AF-682 and the pollination variety of Orange Flesh with symptoms on the fruits. Transmission through seeds has not been proven, but the presence of the fungus on seeds affects the germination and vigor of the plantlets of different varieties (Kuti et al., 1985). Due to the lack of information on the reaction of melon genotypes with symptoms on the fruits, it is important to carry out studies to identify sources of resistance to $M$. roridum.

The determination of the genetic control of resistance is another important aspect in any genetic improvement program aimed at resistance to a given pathogen. There are no reports in the literature on crater rot in fruits. In studies carried out on detached leaves, Kuti \& Ng (1989) found evidence of polygenic inheritance, whereas MacKay et al. (1992) were unable to arrive at conclusive results due to the small degree of contrast between the parent plants.

The aims of the present study were to evaluate the reaction of melon accessions from northeastern Brazil to the fungus $M$. roridum and study the inheritance of resistance to crater rot in melon fruits.

\section{MATERIAL AND METHODS}

Reaction of melon accessions to Myrothecium roridum - The experiment was carried out in the horticulture field of the Universidade Federal Rural do Semi-Árido, in the municipality of Mossoró, Rio Grande do Norte state,

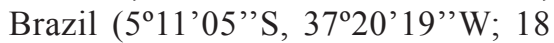
$m$ altitude). The Köppen climatic classification for the region is BSWh' (very dry), with a rainy season in summer and early autumn (Carmo Filho \& Oliveira, 1989).
Thirty accessions of melon collected from different states of northeastern Brazil were evaluated. The accessions were classified into four botanical groups based on Münger \& Robinson (1991) and one undefined group (Table 1). The experiment was carried out with the transplantation of 15-day-old seedlings from 128-cell polystyrene trays. The management practices followed the cultivation needs of Rio Grande do Norte state (Nunes et al., 2004). The field experiment was conducted between September 12 and December 5, 2006. Maximum and minimum temperatures were 33 and $27^{\circ} \mathrm{C}$, respectively. No rainfall was recorded throughout the experimental period.

A randomized block design was employed with two replicates. Each plot was formed by a row of 12 plants. At harvest (65 to 70 days after sowing), three fruits were randomly sampled from each plot for inoculation. The fruits were uniform, with size and coloration characteristic of the commercial maturation of each accession at the time of harvesting.

Inoculation was performed with a strain of $M$. roridum (CMM-609) obtained from the roots of a melon plant with symptoms of crater rot collected from a commercial field in Mossoró, in 2004. The isolate was deposited in the Culture Collection of the Phytopathogenic Fungi "Prof. Maria Menezes" - CMM of the Universidade Federal Rural de Pernambuco (Recife, Pernambuco state, Brazil). The $M$. roridum inoculum was produced in Petri dishes with potato-dextrose-agar (PDA) culture medium and incubated in a BOD incubator for 15 days at $25^{\circ} \mathrm{C}$ with a 12-h light/dark cycle. Spore suspensions were prepared with the addition of sterilized distilled water to the surface of the cultures, filtering with a double layer of gauze and the adjustment of the concentration to $10^{6}$ conidia $\mathrm{mL}^{-1}$ in a hemocytometer.

Melon fruits at commercial maturation stage were washed with soap and water, disinfested by immersion in $0.05 \% \mathrm{NaClO}$ for 5 minutes and left to dry for 45 minutes. Four equidistant sites on the surface of each fruit were injured with aid of a pin cushion. The 
pins had been disinfested by immersion in alcohol for 2 minutes. Each site had a total of 10 wounds measuring approximately $3.0 \mathrm{~mm}$ in depth. A pipette was used to place $0.05 \mathrm{~mL}$ of the $M$. roridum conidial suspension immediately after the injury to the fruits. After inoculation, fruits were maintained for $48 \mathrm{~h}$ on lids of Petri dishes containing hydrophilic cotton moistened with sterile distilled water, and this set placed in moistened plastic bags, forming a humid chamber. The fruits kept in the moist chambers were incubated at ambient conditions $\left(27^{\circ} \mathrm{C}\right.$ and $67 \%$ relative humidity) in the laboratory.

The evaluation of the crater rot severity was performed 5 days after inoculation, with the measurement of external lesion length in two diametrically opposite ways at each inoculated site and calculation of lesion area in $\mathrm{mm}^{2}$ (Senhor, 2006).

Friedman's non-parametric test was applied, with the level of significance set to $5 \%(\alpha=0.05)$. A rank comparison test was then employed for the distinction of the treatments. The statistical analysis was performed using the $\mathrm{R}$ software, version 2.10.1.

Genetic inheritance of the resistance to crater rot - The AF- 682 and UFERSA-05 cultivars were used for the production of populations for the inheritance study. The AF-682 cultivar is a simple hybrid belonging to the yellow type inodorus variety, with a goldyellow, rough-textured rind, white pulp, andromonoic sexual expression and susceptibility to $M$. roridum in the fruit (Senhor et al., 2008). The UFERSA-05 stain belongs to the acidulus botany variety, is not defined within any type of commercial melon, has a smooth yellow rind, elliptical shape, white flesh, dark green foliage, monoic sexual expression and resistance to $M$. roridum in both the seedling and fruit. This line was obtained through five selffecundations of the A-9 accession (Table 1) and has proven resistant to crater rot in all previous assays performed to demonstrate the pathogenicity of the CMM-609 isolate.

The cross between AF-682 and UFERSA-05 line was performed to obtain the $F_{1}$ hybrid. $F_{1}$ plants were selfed to obtain the $\mathrm{F}_{2}$ generation and backcrossed with both parents to obtain the $\mathrm{RC}_{11}$ and $\mathrm{RC}_{12}$ generations.

The experiment was carried out with the transplantation of 12-day-old seedlings from 128-cell polystyrene trays with a commercial substrate. The other cultural practices followed the crop needs of Rio Grande do Norte state (Nunes et al., 2005). The crop season occurred from August 15 to October 17, 2007. Maximum and minimum temperatures were 30 and $26^{\circ} \mathrm{C}$, respectively. No rainfall was recorded throughout the experimental period.

The six populations were cultivated under field conditions in a randomized block design. Two plots with 20 plants were evaluated for the AF-682 $\left(\mathrm{P}_{1}\right)$, UFERSA-05 $\left(\mathrm{P}_{2}\right)$ and $\mathrm{F}_{1}$ populations. Eight plots with 20 plants were evaluated for the $\mathrm{F}_{2}$ population and four plots with 20 plants were evaluated for the backcrossed populations. The fruits from each population were harvested and duly identified. The procedures for fruit disinfestation, $M$. roridum inoculums obtaining, fruit inoculation and disease assessment were the same as those described above.

The following analyses were performed in the study of inheritance: a) evaluation of generations (Mather \& Jinks, 1984) to estimate mean and variance components of the additivedominant model and estimate the number of genes using the GENES software (Cruz, 2006); b) test the hypothesis of monogenic inheritance under different mean degrees of presumed dominance (Oliveira et al., 2003) using the R software version 2.10.1; and c) test the hypothesis of monogenic inheritance and/or the presence of polygenic (or modifying) loci affecting the character based on maximum likelihood estimates (Silva, 2003). The most general model is that which presents a gene of major effect together with polygenes with additive and dominance effects and equal environmental variances in all generations. Independent genes (polygenes and those of major effect) are also considered. The likelihood functions for each model allowed carrying out tests of interests considering different hypotheses. The analyses of the tests were performed using the Monogen software, version 0.1 .

\section{RESULTS AND DISCUSSION}

Reaction in fruits of melon accessions to Myrotecium roridum - Significant differences between accessions were found regarding the reaction to $M$. roridum $\left(\chi^{2}=66.67\right.$; $\mathrm{p}<0.01$ ) (Table 1). Accessions A-9, A-14 and A-30 had the smallest lesion areas (Table 1). None of these accessions are among the commercial types exported by Brazil (Sales Júnior et al., 2006). Accessions A-9 and A-14 belong to the acidulus botanical group and A-30 belongs to the momordica group (Table 1). The use of germplasms from botanical groups that are different from commercially important groups, such as cantaloupensis and inodorus, is a common practice in genetic breeding programs for melons, especially in developed nations, such as the United States of America, France and The Netherlands. In Brazil, there are no studies to date on the introgression of alleles using germplasms from the momordica and acidulus groups.

According to Fergany et al. (2011), the C. melo var. acidulus Naudin is endemic to tropical humid southern India (states of Kerala and Tamil Nadu). Fruits have very long shelf life and tender fruits are consumed as salad or use for 'Sambhar' preparation. 'Sambhar', a vegetable stew based on a broth with tamarind and "toor dal" (small lentils), a dish common in south India and Sri Lanka Tamil cuisines. Ripe fruits are also eaten. Melons from the acidulus group are rare in Brazilian small farms.

C. melo var momordica also denominated snapmelons, is native of India and used in salads or in the form of pickles. The main characteristics of these melons are the low content of soluble solids and the opening ("cracking") of the fruit when ripe. The main use of the Indian melon is as a source of genetic resistance to pests and diseases, such as Fusarium oxysporium, Podosphaera xanthii, 
Table 1. Reaction of melon accessions collected in northeastern Brazil to Myrothecium roridum) (reação de acessos de meloeiro coletados no Nordeste brasileiro a Myrothecium roridum). Mossoró. UFERSA. 2007.

\begin{tabular}{|c|c|c|c|c|}
\hline Accession & Botanical variety & Commercial type & Mean rank & $\operatorname{Area}\left(\mathrm{mm}^{2}\right)$ \\
\hline A-1 & cantaloupensis & Cantaloupe & $80.00 \mathrm{a}^{1}$ & 292.09 \\
\hline A-2 & momordica & Not defined & $51.67 \mathrm{a}$ & 205.84 \\
\hline A-3 & inodorus & Tendral Green & $30.67 \mathrm{a}$ & 147.57 \\
\hline A-4 & momordica & Not defined & $38.33 \mathrm{a}$ & 167.99 \\
\hline A-5 & cantaloupensis & Cantaloupe & $19.00 \mathrm{a}$ & 115.37 \\
\hline A-6 & cantaloupensis & Cantaloupe & $76.00 \mathrm{a}$ & 293.80 \\
\hline A-7 & cantaloupensis & Cantaloupe & $42.00 \mathrm{a}$ & 169.48 \\
\hline A-8 & cantaloupensis & Cantaloupe & $18.67 \mathrm{a}$ & 122.00 \\
\hline A-9 & acidulus & Not defined & $4.50 \mathrm{~b}$ & 15.34 \\
\hline A-10 & inodorus & Yellow & $58.33 \mathrm{a}$ & 230.64 \\
\hline A-11 & cantaloupensis & Cantaloupe & $46.67 \mathrm{a}$ & 170.99 \\
\hline A-12 & momordica & Not defined & $21.67 \mathrm{a}$ & 130.37 \\
\hline A-13 & cantaloupensis & Caipira & $47.50 \mathrm{a}$ & 178.54 \\
\hline A-14 & acidulus & Not defined & $4.50 \mathrm{~b}$ & 15.34 \\
\hline A-15 & cantaloupensis & Cantaloupe & $72.33 \mathrm{a}$ & 259.41 \\
\hline A-16 & acidulus & Oriental & $58.00 \mathrm{a}$ & 188.80 \\
\hline A-17 & Not defined & Cucumber melon & $31.00 \mathrm{a}$ & 149.61 \\
\hline A-18 & cantaloupensis & Cantaloupe & $62.83 \mathrm{a}$ & 223.43 \\
\hline A-19 & cantaloupensis & Cantaloupe & $67.67 \mathrm{a}$ & 236.19 \\
\hline A-20 & inodorus & Pele de sapo & $41.67 \mathrm{a}$ & 176.14 \\
\hline A-21 & cantaloupensis & Charenthais & $22.00 \mathrm{a}$ & 133.78 \\
\hline A-22 & cantaloupensis & Cucumber melon & $20.00 \mathrm{a}$ & 126.96 \\
\hline A-23 & momordica & Not defined & $84.00 \mathrm{a}$ & 322.44 \\
\hline A-24 & cantaloupensis & Cantaloupe & $31.33 \mathrm{a}$ & 151.75 \\
\hline $\mathrm{A}-25$ & Not defined & Cucumber melon & $71.00 \mathrm{a}$ & 247.37 \\
\hline A-26 & cantaloupensis & Cantaloupe & $47.50 \mathrm{a}$ & 178.54 \\
\hline A-27 & cantaloupensis & Charenthais & $50.67 \mathrm{a}$ & 185.43 \\
\hline A-28 & cantaloupensis & Cantaloupe & $54.00 \mathrm{a}$ & 182.15 \\
\hline A-29 & cantaloupensis & Cantaloupe & $56.50 \mathrm{a}$ & 274.78 \\
\hline A-30 & momordica & Not defined & $10.00 \mathrm{a}$ & 44.51 \\
\hline$\chi^{2}$ & & & $66.67 * * 2$ & \\
\hline
\end{tabular}

${ }^{1}$ Ranks followed by the same letter did not differ from each other at $5 \%$ probability (nonparametric multiple comparison) (ordenamentos seguidos pela mesma letra não diferem entre si a $5 \%$ de probabilidade (comparações múltiplas não-paramétricas)). ${ }^{2}$ Chi-square value significant at $1 \%$ probability by the Friedman's test (valor de Qui-quadrado significativo a $1 \%$ de probabilidade pelo teste de Friedman).

Pseudoperonospora cubensis and Aphis gossypii (Dhillon et al., 2007).

The snapmelon assessed in the present study is grown on small farms in northeastern Brazil and has not yet been evaluated in genetic breeding programs for its reaction to the main pathogens found in the Mossoró-Assu region, such as $P$. xanthii, Rotylenchulus reniformis and Acidovorax citrulli.
The identification of resistant melon accessions will allow advancements in the ongoing work against economically important diseases (Sinclair, 2003).

While the A-9, A-14 and A-30 accessions have low-quality fruits due to the low content of soluble solids

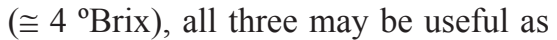
sources of resistance to $M$. roridum in genetic breeding programs. Accessions from the momordica group have been successfully used for creation of melon cultivars with resistance to powdery mildew. The line MR-1 is resistant to the majority of races of the $P$. xanthii throughout the world and is used as a genitor of modern resistance cultivars (Fukino et al., 2004). No reports were found in the literature on the resistance to $M$. roridum of accessions belonging to the momordica and acidulus groups. The A-9 and A-14 accessions of the group acidulus have melons with a high degree of firmness (around $35 \mathrm{~N}$ ) and approximately 12 weeks of postharvest conservation. These melons have considerable potential for increasing the shelf life of melons from the inodorus group, and especially cantalupensis group, such as the types Galia, Charenthais and Cantaloupe.

It should be stressed that only one isolate of $M$. roridum was used in the present study. Considering the genetic variability among isolates with regard to pathogenicity (Lima et al., 1997; Senhor, 2006), further evaluations are needed with other isolates collected from melon-producing regions in order to achieve a more reliable assessment of the degree of resistance of the accessions.

Nonetheless, the results of the present study indicate the potential of the melon accessions collected from small farms in northeastern Brazil. These accessions are sources of alleles that could be used in melon breeding programs. Thus, the variability in germplasm banks should be conserved and characterized to obtain important information from both the practical and theoretical standpoints, as in inheritance studies.

Inheritance of resistance to crater rot in melons

Estimates of genetic and phenotype parameters and monogeny test - The hybrid AF-682 cultivar had a larger lesion area in comparison to the UFERSA-05 line (Table 2), which confirms its greater susceptibility to M. roridum, as reported by Senhor et al. (2008). This contrast is important in inheritance studies, as it allows greater variability in the segregating generations (Sinclair, 2003), as demonstrated by the 
Table 2. Average values of lesion area of the fruit $\left(\mathrm{mm}^{2}\right)$ of generations $\mathrm{P}_{1}, \mathrm{P}_{2}, \mathrm{~F}_{1}, \mathrm{~F}_{2}, \mathrm{RC}_{11}$ and $\mathrm{RC}_{12}$, components of mean and dominance mean degree of (DMD) of the reaction of the melon fruits to Myrothecium roridum (média da área lesionada do fruto $\left(\mathrm{mm}^{2}\right)$ das gerações $\mathrm{P}_{1}, \mathrm{P}_{2}, \mathrm{~F}_{1}, \mathrm{~F}_{2}, \mathrm{RC}_{11}$ e $\mathrm{RC}_{12}$, componentes de média e grau médio de dominância (DMD) da reação de frutos de meloeiro a Myrothecium roridum). Mossoró, UFERSA, 2007.

\begin{tabular}{lc}
\hline Generation & Mean \\
\hline AF-682 & 379.76 \\
UFERSA-05 & 172.94 \\
$\mathrm{~F}_{1}($ AF-682 x UFERSA-05) & 307.00 \\
$\mathrm{~F}_{2}$ & 339.34 \\
$\mathrm{RC}_{11}\left(\mathrm{~F}_{1} \times\right.$ AF-682) & 401.28 \\
$\mathrm{RC}_{12}\left(\mathrm{~F}_{1} \times\right.$ UFERSA-05) & 220.37 \\
$\mathrm{~m}^{1}$ & $287.25 \pm 11.34$ \\
{$[\mathrm{a}]^{2}$} & $116.26 \pm 11.05$ \\
{$[\mathrm{~d}]^{3}$} & $45.89 \pm 21.02$ \\
$\chi_{\mathrm{c}}^{2}$ & $0.19^{\mathrm{ns}}$ \\
$\mathrm{DMD}^{5}$ & 0.57 \\
$\eta^{6}$ & 5.52 \\
\hline
\end{tabular}

${ }^{1} \mathrm{~m}=$ homozygotes mean (média dos homozigotos); ${ }^{2}[\mathrm{a}]=$ additive effect of genes (efeito aditivo dos genes); ${ }^{3}[\mathrm{~d}]=$ effect of dominance deviation (efeito do desvio de dominância); ${ }^{4} \chi^{2}=$ Chi-square (Qui-quadrado); ${ }^{5} \mathrm{DMD}=$ dominance mean degree (grau médio de dominância); ${ }^{6} \eta=$ number of genes (número de genes).

Table 3. Variances of generations $\mathrm{P}_{1}, \mathrm{P}_{2}, \mathrm{~F}_{1}, \mathrm{~F}_{2}, \mathrm{RC}_{11}$ and $\mathrm{RC}_{12}$, estimates of variance components of additive-dominant model and broad-sense heritability of the reaction of melon fruits to Myrothecium roridum (variâncias das gerações $\mathrm{P}_{1}, \mathrm{P}_{2}, \mathrm{~F}_{1}, \mathrm{~F}_{2}, \mathrm{RC}_{11}$ e $\mathrm{RC}_{12}$, estimativas dos componentes de variância do modelo aditivo-dominante e herdabilidade no sentido amplo da área lesionada do fruto de meloeiro a Myrothecium roridum). Mossoró, UFERSA, 2007.

\begin{tabular}{|c|c|}
\hline Generation & Variance \\
\hline AF-682 & 12151.28 \\
\hline UFERSA-05 & 10421.39 \\
\hline $\begin{array}{l}\mathrm{F}_{1}(\mathrm{AF}-682 \times \mathrm{UFER}- \\
\text { SA-05) }\end{array}$ & 10097.58 \\
\hline $\mathrm{F}_{2}$ & 46313.18 \\
\hline $\mathrm{RC}_{11}\left(\mathrm{~F}_{1} \times \mathrm{AF}-682\right)$ & 30425.41 \\
\hline $\mathrm{RC}_{12}\left(\mathrm{~F}_{1} \times\right.$ UFERSA-05) & 31750.73 \\
\hline$\hat{\sigma}_{E}^{2}$ & 10890.08 \\
\hline$\hat{\sigma}_{G}^{2}$ & 35423.09 \\
\hline$\hat{\sigma}_{A}^{2}$ & 30486.44 \\
\hline$\hat{\sigma}_{D}^{2}$ & 4936.66 \\
\hline$\hat{h}_{r}^{2}$ & 65.82 \\
\hline$\hat{h}_{a}^{2}$ & 76.48 \\
\hline \multicolumn{2}{|c|}{$\begin{array}{l}\hat{\sigma}_{E}^{2}=\text { environmental variance (variância ambiental); } \hat{\sigma}_{G}^{2}=\text { genetic variance (variância } \\
\text { genética); } \hat{\sigma}_{A}^{2}=\text { additive variance (variância aditiva); } \hat{\sigma}_{D}^{2}=\text { dominance variance (variância } \\
\text { de dominância); } \hat{\boldsymbol{h}}_{r}^{2}=\text { narrow-sense heritability (herdabilidade no sentido restrito); } \hat{\boldsymbol{h}}_{a}^{2}= \\
\text { broad-sense heritability (herdabilidade no sentido amplo). }\end{array}$} \\
\hline
\end{tabular}

variance estimates in the present study (Table 3).

The adequacy of the additivedominant model was determined by the non-significance of the chi-square $\left(\chi^{2}\right)$ estimates, indicating that deviations were due to random (Table 2).

Additive and dominance effects are involved in the inheritance of the reaction of the melon fruits to $M$. roridum. The estimate of the mean degree of dominance demonstrated incomplete dominance, as the estimate (0.57) was less than 1.0.

Broad-sense heritability measures how much phenotype variance is due to genetic causes (additive and nonadditive) and narrow-sense heritability only additive effects. Values closer to $100 \%$ denote a greater likelihood of selecting superior genotypes (Falconer \& Mackay, 1996). In the present study, values were slightly above 50\%, indicating intermediate heritabilities (Table 3).

The $\chi^{2}$ estimates referring to the monogenic inheritance test were higher than the tabulated value of 11.07 $(p \leq 0.05)$ for all presumed degrees of dominance (Figure 1), demonstrating that the character in question is controlled by more than one gene. This finding is in accordance with the classic estimate of 5.52 genes (Table 2).

Test of genetic models using maximum likelihood function Comparing models 1 and 5, facing the existence of major gene more polygenes, with only polygenes, the null hypothesis $\left(\mathrm{H}_{0}\right)$ was rejected, thereby evidencing the existence of a gene of major effect (Table 4). The test between Models 1 and 7, which compare the existence of a gene of major effect plus polygenes to a gene of major effect alone, was significant (Table 4), evidencing the presence of polygenes in the control of the character in question (Silva, 2003).

No reports were found in the literature regarding the inheritance of reaction to crater rot, but only in relation to symptoms on leaves, which are practically not observed in the MossoróAssu region. Studying resistance to $M$. roridum in melon leaves through diallel cross, Kuti \& Ng (1989) found complex inheritance. However, studying 
Table 4. Hypothesis test of hierarchical genetic models for resistance of melon to Myrothecium roridum (testes de hipóteses de modelos genéticos hierárquicos para resistência de meloeiro a Myrothecium roridum). Mossoró, UFERSA, 2007.

\begin{tabular}{|c|c|c|c|}
\hline Test between models & Freedon degrees & $\chi_{c}^{2}$ & Probability \\
\hline 1 vs. 2 & 3 & 9.31 & 0.025424171 \\
\hline 1 vs. 3 & 1 & 0.13 & 0.713055231 \\
\hline 1 vs. 4 & 4 & 11.76 & 0.019178798 \\
\hline 1 vs. 5 & 5 & 10.02 & 0.006655237 \\
\hline 1 vs. 6 & 6 & 20.54 & 0.000988732 \\
\hline 1 vs. 7 & 5 & 10.39 & 0.024720986 \\
\hline 1 vs. 8 & 6 & 12.07 & 0.060395150 \\
\hline 1 vs. 9 & 7 & 230.02 & 0.000000801 \\
\hline 2 vs. 4 & 1 & 2.45 & 0.117183526 \\
\hline 2 vs. 6 & 2 & 11.23 & 0.003642435 \\
\hline 2 vs. 7 & 2 & $*$ & $*$ \\
\hline 2 vs. 8 & 2 & 2.75 & 0.430138018 \\
\hline 2 vs. 9 & 3 & 220.71 & 0.000000731 \\
\hline 3 vs. 5 & 4 & 9.88 & 0.001662245 \\
\hline 3 vs. 6 & 1 & 20.40 & 0.000415203 \\
\hline 3 vs. 8 & 5 & 11.93 & 0.035673356 \\
\hline 3 vs. 9 & 6 & 8.77 & 0.000000949 \\
\hline 4 vs. 6 & 1 & 229.89 & 0.003052642 \\
\hline 4 vs. 8 & 2 & 0.30 & 0.858400342 \\
\hline 4 vs. 9 & 3 & 218.26 & 0.000000722 \\
\hline 5 vs. 6 & 3 & 10.52 & 0.014646133 \\
\hline 5 vs. 9 & 5 & 220.00 & 0.000000752 \\
\hline 6 vs. 9 & 2 & 209.48 & 0.000000724 \\
\hline 7 vs. 8 & 1 & 10.67 & 0.001085810 \\
\hline 7 vs. 9 & 2 & 228.63 & 0.000000658 \\
\hline 8 vs. 9 & 1 & 9.31 & 0.002277145 \\
\hline
\end{tabular}

*Negative value, perhaps due to convergence problems (valor negativo, talvez devido a problemas de convergência).

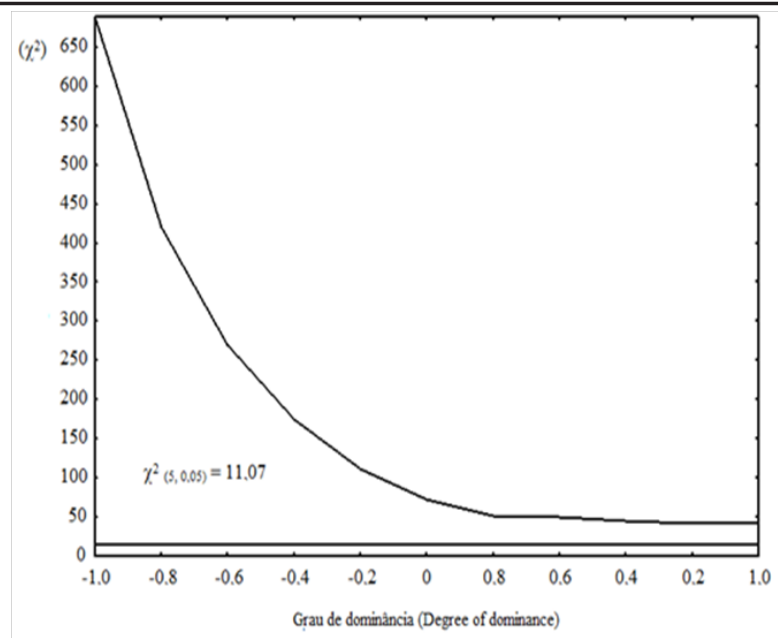

Figure 1. Hypothesis test of monogenic inheritance under different mean degrees of dominance for the reaction of the fruits of melon Myrothecium roridum (teste de hipótese da herança monogênica sob diferentes graus médios de dominância para reação de frutos de meloeiro a Myrothecium roridum). Mossoró, UFERSA, 2007. the inheritance of the same character in three cross-breeds ('Perlita' $x$ 'Iroquois'; 'Perlita' $x$ 'Hales Best'; 'Iroquois' $x$ 'Hales Best') and their reciprocals, MacKay et al. (1992) were unable to arrive at conclusive results due to the small degree of contrast between the genitors used to generate the segregating populations.

Due to the variability in the pathogen population (Noronha et al., 2008), other isolates should be studied in future studies on the inheritance of resistance to crater rot. Genetic control studies involving other parts of the plant affected by $M$. roridum should be carried out to determine whether there is an association between the resistance in different parts of the plant.

The complexity of the inheritance of resistance to crater rot in melons is a hindrance to breeding programs which aim at obtaining resistant cultivars to this disease, making this process slow and possible only by means of an increase in the frequency of favorable alleles through recurrent selection.

\section{REFERENCES}

BRUTON BD. 1996. In: ZITTER TA; HOPKINS DL; THOMAS CE (eds). Compedium of cucurbit diseases. St. Paul: APS Press. p. 49-50.

CARMO FILHO F; OLIVEIRA OF. 1989. Mossoró: um município do semi-árido nordestino - características e aspectos florísticos. Mossoró: ESAM. 62p. (Coleção Mossoroense, Série B, n. 672).

CRUZ CD. 2006. Programa GENES: Biometria. Viçosa: UFV. 382p.

DHILLON NPS; RANJANA R; SINGH K; EDUARDO I; MONFORTE AJ; PITRAT M; DHILLON NL; SINGH PP. 2007. Diversity among landraces of Indian Snapmelon (Cucumis melo var. momordica). Genetics Resources Crop Evolution 54: 1267-1283.

DIAS RCS; COSTA ND; CERDAN C; SILVA PCG, QUEIROZ MA; ZUZA F; LEITE LAS; PESSOA PFA; TERAO DA. 1998. Cadeia produtiva do melão. In: CASTRO AMG; LIMA SMV; GOEDERT WJ; FILHO, AF; VASCONCELOS JRP. Cadeias produtivas e sistemas naturais: prospecção tecnológicas. Brasília: SPI. p.440-493.

FALCONER DS; MACKAY TFC. 1996. Introduction to quantitative genetics. 4. ed. London: Longman. 464p.

FERGANY M; KAUR B; MONFORTE AJ; PITRAT M; RYS C; LECOQ H; DHILON NPS; DHALIWAL SS. 2011. Variation in melon (Cucumis melo) landraces adapted to the humid tropics os southern India. Genetic 
Resources and Crop Evolution 58: 225-243.

FUKINO N; KUNIHISA M; MATSUMOTO S. 2004. Characterization of recombinant inbred lines derived from crosses in melon (Cucumis melo L.) 'PMAR No5' x 'Harukei N³'. 2004. Breeding Science 54: 141-145.

KUTI J; NG TJ; BEAN GA. 1985. Effect of inoculation with Myrothecium roridum Tode ex Fries on seed germination and early seedling growth of 12 cultivars of muskmelon (Cucumis melo). Cucurbit Genetics Cooperative Report 8: 44-45.

KUTI JO; NG TJ. 1989. Combining ability estimates for muskmelon tolerance to Myrothecium roridum and its toxic metabolite, roridin E. Journal of the American Society for Horticultural Science 114: 319321.

KUTI JO; NG TJ; BEAN GA. 1987. Reactions of muskmelon cultigens to Myrothecium roridum. Hortscience 22: 635-637.

LIMA GSA; OLIVEIRA SMA; BEZERRANETO E; MENEZES M. 1997. Reação de cultivares de melão a isolados de Myrothecium roridum. Summa Phytopathologica 23: 135-139.

MACKAY WA; NG TJ; HAMMERSCLAG FA. 1992. Screening of Cucumis melo parental, $\mathrm{F}_{1}, \mathrm{~F}_{2}$ and backcross population for determination of the genetic basis of tolerance to Myrothecium roridum. Cucurbit Genetics Cooperative Report 15: 57-58.

MATHER K; JINKS JL. 1984. Biometrical genetics. 3. ed. London: Chapman \& Hall. $382 \mathrm{p}$.

MINISTÉRIO DO DESENVOLVIMENTO DA INDÚSTRIA E COMÉRCIO. Exportação brasileira de melões frescos. Disponível em: $<$ http://aliceweb.desenvolvimento.gov.br>. Acesso em: 28 de novembro, 2011.

MÜNGER HM; ROBINSON RW. 1991.
Nomenclatura of Cucumis melo L. Cucurbit Genetics Cooperative Report 14: 43-45.

NORONHA MA; MICHEREFF SJ; XAVIER FILHA MS; MOREIRA PAA; REIS A; SALES JR R. 2006. Reação de genótipos de meloeiro a Myrothecium. Horticultura Brasileira 24: 495-498.

NORONHA MA; MICHEREFF SJ; MOREIRA PAA; XAVIER FILHA, MS; SALES JUNIOR R; MIZUBUTI ESG. 2008. Variabilidade de isolados de Myrothecium roridum provenientes de meloeiro cultivado no Estado do Rio Grande do Norte. Tropical Plant Pathology 33: 432-438.

NUNES GHS; SANTOS JÚNIOR JJS; ANDRADE FV; BEZERRA NETO F; ALMEIDA AHB; MEDEIROS DC. 2004. Aspectos produtivos e de qualidade de híbridos de melão cultivados no agropolo MossoróAssu. Horticultura Brasileira 22: 744-747.

NUNES GHS; SANTOS JÚNIOR JJ; ANDRADE FV; BEZERRA NETO F; MENEZES JB; PEREIRA EWL. 2005. Desempenho de híbridos do grupo inodorus em Mossoró. Horticultura Brasileira 23: 90-94.

OLIVEIRA ACB; MALUF WR; PINTO JEBP; AZEVEDO SM. 2003. Resistance to papaya ringspot virus in Cucurbita pepo L. introgressed from an interspecific $C$. pepo $\mathrm{x}$ C. moschata cross. Euphytica 132: 211-215.

SALES JÚNIOR R; DANTAS F; SALVIANO AM; NUNES GHS. 2006. Aspectos qualitativos do melão exportado pelo porto de Natal-RN. Ciência Rural 36: 286-289.

SENHOR RF. 2006. Epidemiologia da podridãode-cratera em frutos de meloeiro. Recife: UFRPE. 76p. (Dissertação mestrado).

SENHOR RF; CÂMARA MPS; PRICHOA LF; LIMA MB; SALES JR R; MICHEREFF SJ. 2008. Influência do método de inoculação, intensidade do ferimento e idade do fruto na severidade da podridão-de-cratera em melão. Summa Phytopathologica 34: 232-237.

SILVA DMW; PEREIRA GFA; OLIVEIRA SMA; MENEZES M. 1993. Reação de genótipos de melão a Myrothecium roridum em Pernambuco. Summa Phytopathologica 19: 42.

SILVA DMW; MENEZES M; OLIVEIRA SMA; PEREIRA GF. 1996. Ocorrência de Myrothecium roridum em melão em Mossoró, Rio Grande do Norte. Fitopatologia Brasileira, 21: 519.

SILVA WP. 2003. Estimadores de máxima verossimilhança em misturas de densidades normais: uma aplicação em genética. Lavras: UFLA. 2003. 60p. (Dissertação mestrado).

SINCLAIR JW. 2003. Screening for resistance to cucurbit yellow stunting disorder virus, gummy stem blight, and monosporascus root rot and detection of RAPD markers associated with QTL for soluble solids, sugars, and vitamin c in melon (Cucumis melo L.). Weslaco: Texas A\&M University in College Station. 2003. 135 p. (Tese doutorado).

TANAKA K; NISHITANI A; AKASHI Y; SAKATA Y; NISHIDA H; YOSHINO H; KATO K. 2006. Molecular characterization of south and east Asian melon, Cucumis melo L., and origin of group Conomon var. makuva and var. conomom revealed by RAPD analysis. Euphytica 153: 233-247.

TAVARES SCCH. 2002. Melão: fitossanidade. Brasília: Embrapa Informação Tecnológica. $87 \mathrm{p}$.

VIANA FMP; SANTOS AA; FREIRE FCO; CARDOSO JE; VIDAL JC. 2001. Recomendações para o controle das principais doenças que afetam a cultura do melão na região Nordeste. Fortaleza: Embrapa Agroindústria Tropical. $6 \mathrm{p}$ 